Similar activities have been planned for the next couple of summers to provide a satisfactory amount of background information for the interpretation of the aeromagnetic data.

\title{
References
}

Henderson, G. 1969: The Precambrian rocks of the Egedesminde-Christianshåb area, West Greenland. Rapp. Grønlands geol. Unders, 23, 37 pp.

Thorning, L. 1976: Aeromagnetic surveys in southern and central West Greenland between $63^{\circ}$ and $71^{\circ}$ N. Rapp. Grønlands geol. Unders. 80, 61-65.

Thorning, L. 1977: Continuation of the aeromagnetic surveys in southern and central West Greenland between $64^{\circ}$ and $72^{\circ}$ N. Rapp. Grønlands geol. Unders. 85, 34-37.

L.B.J., C.M., B.S.M., S.A.P., Laboratoriet for Geofysik, Geologisk Institut, University of Arhus, Finlandsgade 8, 8200 Aarhus N, Denmark.

\section{Nagssugtoqidian deformation and Kangâmiut dyke intrusion in the Søndre Strømfjord area, West Greenland}

\author{
F. Kalsbeek and H. P. Zeck
}

This note describes the age relationships between Kangâmiut dyke intrusion and Nagssugtoqidian deformation based on detailed mapping of dyke exposures in the summer of 1977 in the inner part of the Søndre Strømfjord area (fig. 42). Many dyke exposures were visited, six of them were studied in detail and sampled for geochemical work. Maps at $1: 1000$ scale were prepared of two dykes.

The Nagssugtoqidian deformation has been subdivided into two main phases: Nag. 1, lateral shear, pre-dating and in part synchronous with the intrusion of the Kangâmiut dykes, and Nag. 2, post-dyke thrusting and deformation (Bridgwater et al., 1973).

The Nag. 1 deformation was thought to be largely restricted to the coastal area between Itivdleq and Holsteinsborg (fig. 42) were the Nag. 2 post-dyke thrusting has not been active. Here, undeformed Kangâmiut dykes have intruded into Nag. 1 shear zones and locally evidence was found for gross contemporaneity of Nag. 1 deformation and dyke intrusion. In the eastern (inland) area, the main Nagssugtoqidian deformation (Nag. 2) was thought to considerably overlap the southern limit of the earlier movements, so that little evidence of Nag. 1 deformation was preserved (Escher et al., 1976a). However, some dykes also here were found emplaced into early Nagssugtoqidian shear zones, sometimes with very irregular margins, suggesting synkinematic emplacement. 
In the inland area a $20-30 \mathrm{~km}$ wide zone south of the main Nagssugtoqidian boundary is characterised by the occurrence of concordant shear zones along the Kangâmiut dykes. These shear zones were regarded as post-dating the dyke intrusion (Escher et al., 1975, figs 5-7). Within these shear zones the brownish, poorly foliated hypersthene gneisses which form most of the country rock have been retrogressed to strongly foliated, greyish white, biotite gneisses. A chemical investigation of the various gneiss types by the writers (unpublished) shows that both the Nagssugtoqidian biotite gneisses north of the main Nagssugtoqidian boundary, and samples from the shear zones along the dykes in the Archaean terrain, are enriched in $\mathbf{R b}$ compared to the bulk of the Archaean gneisses. This prompted us to revisit the area in 1977, especially to sample the white gneisses along the dyke margins.

Contrary to earlier reports, it was found in all cases studied that the shearing and retrogression of the gneisses took place prior to the intrusion of the dykes. Although the shear zones run roughly parallel to the dyke margins, in detail the dykes commonly truncate the well-developed foliation in the biotite gneisses that form the shear zones.

The white shear zones into which the dykes have intruded are generally only a few metres wide. The strongly foliated gneisses in the shear zones grade outward into white gneisses with increasingly well-preserved original structures and these in turn grade into the buff-brown hypersthene gneisses. Concurrently the strike of the foliation changes (fig. 16).

Apart from dykes with associated shear zones, dykes were found in direct contact with the brownish hypersthene gneisses. White shear zones without associated dykes also occur.

The dykes investigated in detail had NE to NNE trends; the associated shear zones all showed a sinistral sense of shear on subvertical shear planes. One ESE-trending shear zone (without associated dyke) was studied, and resembled the NNE-trending shear zones in every respect. The sense of shear movement in this shear zone could not be determined. Nevertheless it seems likely that the two shear directions are conjugate and relate to a compression in a NW-SE direction as in the coastal area (Escher et al., 1976b).

Several of the dykes studied have very irregular outlines; locally this is evidently due to deformation during or after the intrusion. Thinner dykes may show well-developed folds (fig. 16). The strong foliation in the adjoining gneisses may run parallel to the axial plane of these folds (possibly behaving as axial plane foliation in relation to the folds; fig. 16) or the gneiss foliation itself is folded together with the dyke rock (fig. 17). Sheared and recrystallised dyke rocks (amphibolite) may occur in narrow zones at the margins of the dykes or as wider zones within the dykes, sometimes oblique to the margins.

A preliminary $\mathrm{Rb}-\mathrm{Sr}$ isotope investigation of the gneisses in the shear zones suggests that the Nag. 1 shear zones were initiated already in late Archaean time (see Kalsbeek \& Zeck, this report), although other interpretations of the data are possible. The dykes were intruded much later than this. Two dykes from the coastal area have given a $\mathrm{Rb}-\mathrm{Sr}$ whole-rock isochron age of $1950 \pm 60 \mathrm{~m}$.y. (Kalsbeek et al., in prep.) and samples from six Kangâmiut dykes from the present area, although not defining a proper isochron, suggest ages in order of 1900-2300 m.y. It therefore is possible that the emplacement of the dykes and the late Nag. 1 shearing associated with it made use of old shear zones which had already been present for hundreds of millions of years. 


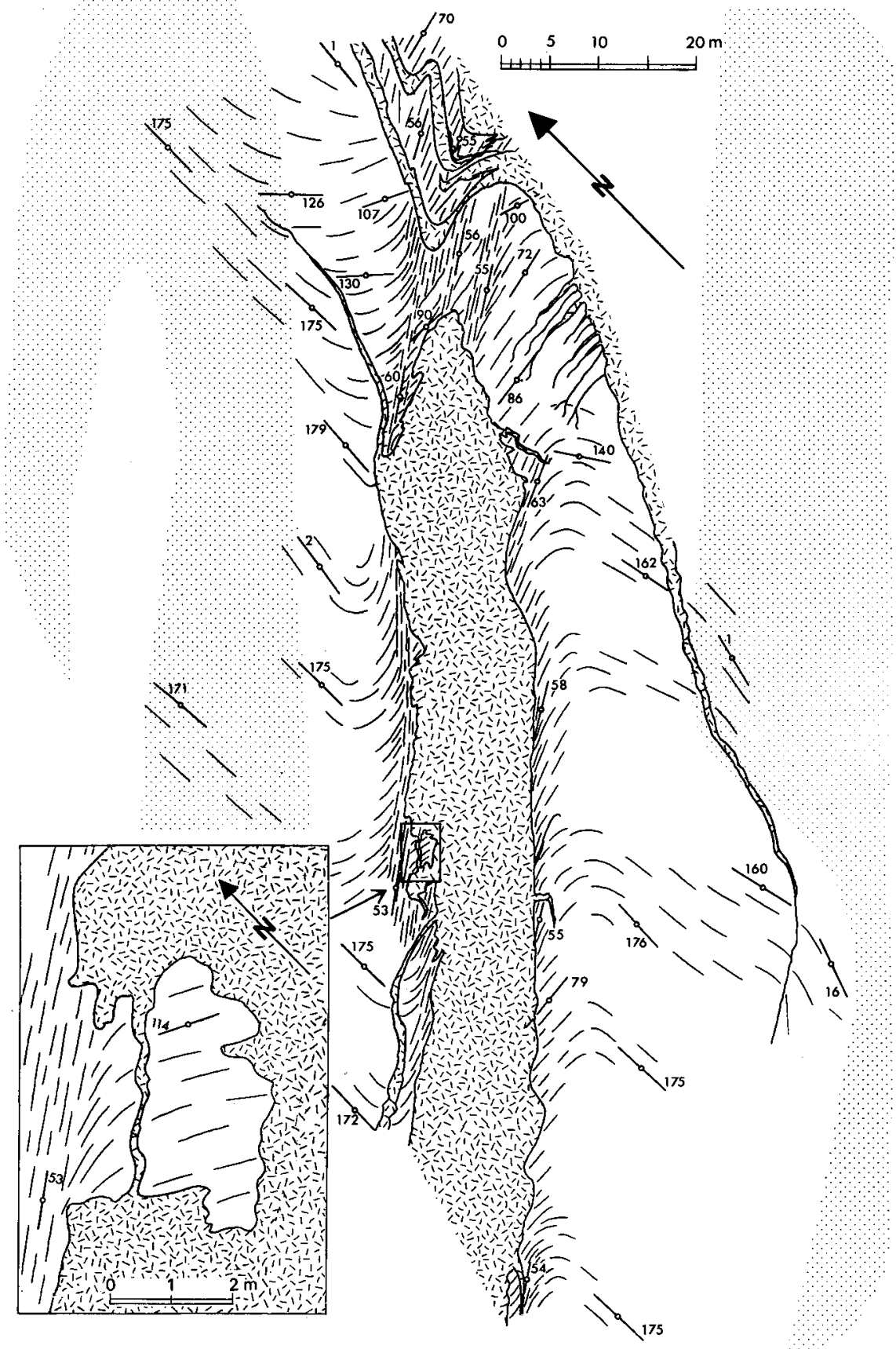

Fig. 16. Map of a Kangâmiut dyke in the area south-east of Søndre Strømfjord. Locality: $66^{\circ} 25^{\prime} \mathrm{N}-51^{\circ} 02^{\prime} \mathrm{W}$. Randomly oriented dashes: basic dyke rock; white: light coloured biotite gneisses; dotted: buff-brown hypersthene gneisses. Variable degree of foliation schematically indicated. 
Fig. 17. Detail of irregular contact between Kangâmiut dyke and strongly foliated biotite gneiss. Locality: $66^{\circ} 41.5^{\prime} \mathrm{N} ; 50^{\circ} 37^{\prime} \mathrm{W}$.

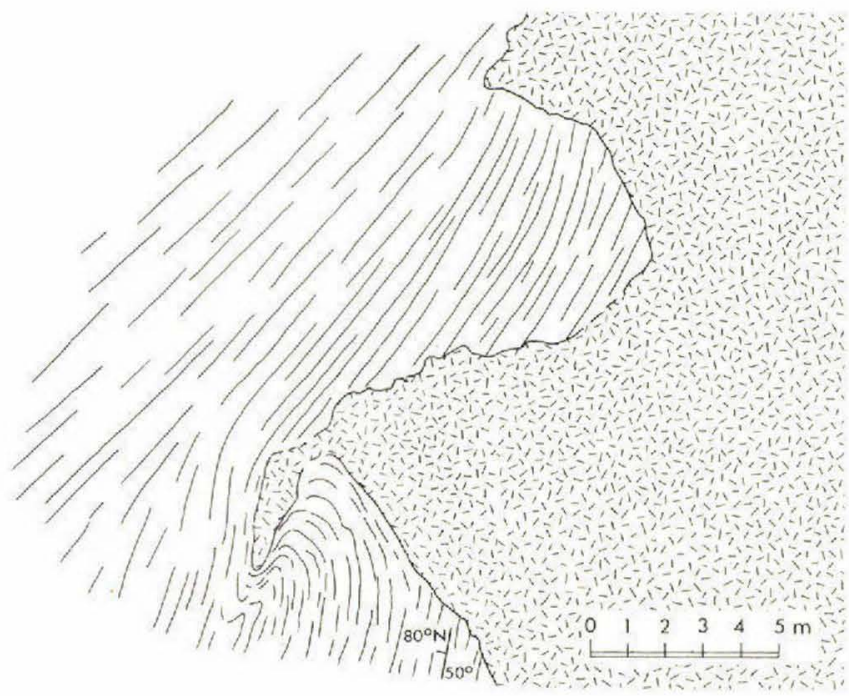

\section{References}

Bridgwater, D., Escher, A., Nash, D. F. \& Watterson, J. 1973: Investigations on the Nagssugtoqidian boundary between Holsteinsborg and Kangâmiut, central West Greenland. Rapp. Gronlands geol. Unders. 55, 22-25.

Escher, A., Escher, J. C. \& Watterson, J. 1975: The reorientation of the Kangâmiut dike swarm, West Greenland. Can. J. Earth Sci. 12, 158-173.

Escher, A., Sørensen, K. \& Zeck, H. P. 1976a: Nagssugtoqidian mobile belt in West Greenland. In Escher, A. \& Watt, W. S. (edit.) Geology of Greenland 76-95. Copenhagen: Geol. Surv. Greenland.

Escher, A., Jack, S. \& Watterson, J. 1976b: Tectonics of the North Atlantic Proterozoic dyke swarm. Phil. Trans. R. Soc. Lond. A 280, 529-539.

Kalsbeek, F., Bridgwater, D. \& Zeck, H. P. in prep.: A $1950 \pm 60$ Ma Rb-Sr whole-rock isochron age from two Kangâmiut dykes and the timing of the Nagssugtoqidian (Hudsonian) orogeny in West Greenland. 